\title{
Accountability by the accountable self: The case of Leone Wollemborg
}

\author{
Eleonora Masiero \\ Ca' Foscari University of Venice, Venice, Italy
}

\begin{abstract}
The accounting history literature has mostly concentrated on depicting how accountability practices evolve with respect to the organisational and social contexts, leaving at the margins explorations of the role of the 'accountable self' in this process. To extend this literature, the present study examines how the economist and landowner Leone Wollemborg (1859-1932) acted as an 'accountable self', explaining his own actions to the 'other', to promote a new organisational model aimed at solving the credit issue affecting the rural population. Based on archival material, the article explores Wollemborg's biography and develops a content analysis of his discourses. The findings show that, by making a pervasive use of face-toface narrative accountability, Wollemborg obtained trust and engagement of external potential stakeholders, thus expanding the rural credit cooperatives (Raiffeisen-style). This research facilitates understanding of the relevance for the initiator of a new organisational model to act as an 'accountable self'.
\end{abstract}

\section{Keywords}

accountability, accountable self, accounting history, Leone Wollemborg, rural credit cooperatives

\section{Introduction}

The study of the background and comportment of individuals is an important theme in accounting history. Previous research has focused on historically important personalities related to the accounting profession to illustrate their contribution as initiators in the academic or accounting fields (e.g. Carnegie et al., 2000; Carnegie and Williams, 2001; Clarke, 2005; Cooper, 2008; Parker, 2014; Romeo and Rigsby, 2008). However, the role played by an initiator acting as an 'accountable self' to promote a new organisational model is left unexplored. In this regard, seminal studies recognised the 'accountable self' as a key unit through which to analyse accountability (Boland and Schultze, 1996; Bovens, 2010; McKernan, 2012; McKernan and MacLullich, 2004; Munro and Mouritsen, 1996; Roberts, 1991, 1996; Roberts and Scapens, 1985; Sinclair, 1995; Willmott, 1996). Accounting history literature has mostly concentrated on depicting how accounting (Abeysekera, 2005; Barnes, 2007; Chandler, 2016; Fülbier and Klein, 2015; Platonova, 2009;

\section{Corresponding author:}

Eleonora Masiero, Department of Management, Ca' Foscari University of Venice, San Giobbe, Cannaregio 873, 30I2I Venice (VE), Italy

Email: eleonora.masiero@unive.it 
Sokolov, 2015; Walker, 2008) and accountability practices (Antonelli et al., 2017; Fowler and Cordery, 2015; Jacobs and Walker, 2004; Killian, 2015; Oakes and Young, 2008; Rammal and Parker, 2012; Sargiacomo and Gomes, 2011) evolve with respect to the organisational and social contexts, leaving at the margins explorations of the role of the 'accountable self' in this process. Among the few exceptions, there is the work of Evans and Pierpoint (2015), which explored directors' accountability in relation to impression management, and the paper of Oakes and Young (2008) exploring how accountability was conceptualised and practised within Hull House, by focusing on the founder's activities.

To extend this literature, the present study examines how the economist and landowner Leone Wollemborg (from now on, Wollemborg) acted as an 'accountable self', explaining his actions to the 'other', to promote a new organisational model aimed at solving the credit issue affecting the rural population. In 1883, Wollemborg introduced and successfully expanded in the Italian context a new organisational model (Dalton, 1935; Leonardi, 2012; Luzzato, 1932; Marconato, 1984): the rural credit cooperative (Raiffeisen-style). Wollemborg was part of the elite and he felt his own responsibility to solve the dreadful economic conditions affecting poor farmers living in the territory (Marconato, 1984).

By considering the stream of literature dealing with the initiators ('first'), conceived as key personalities or innovators (Carnegie and Williams, 2001: 105), the present study explores Wollemborg's biography and develops a content analysis of his discourses. In this article, accountability is conceptualised as 'the capacity and willingness' of the 'accountable self' 'to give explanations for conduct ... with a credible story of what happened, and a calculation and balancing of competing obligations, including moral ones' (Boland and Schultze, 1996: 62).

This study is structured as follows. The next section examines the accountability literature relevant to the conceptual framework, before presenting the research method. The article then illustrates the setting where Wollemborg's activity took place by describing the nineteenth-century northern Italian socioeconomic context, the issues affecting the rural population and the key characteristics of the rural credit cooperatives. Subsequently, the article progresses to an exploration of Wollemborg's biography, activities and accountability practices. Finally, discussion and conclusions are provided.

\section{Accountability from the self: a frame}

Social human activities take place in a specific time and place, and are constantly repeated by social actors who, through interaction, continuously monitor their own and other members' actions (Giddens, 1984). As a social relation (Bovens, 2010; Munro and Mouritsen, 1996; Roberts and Scapens, 1985; Willmott, 1996), accountability is shaped by the sociohistorical contexts in which it is embedded (Killian, 2015; Messner, 2009; Willmott, 1996) and by the person responsible for discharging it, because the way in which the 'accountable self' constructs and provides accountability affects its relationship with the 'other' (Boland and Schultze, 1996; McKernan and MacLullich, 2004; Roberts, 1996; Sinclair, 1995; Willmott, 1996). To provide accountability for self-conduct in front of the 'other', the 'accountable person' should distinguish 'itself' from the 'other' (Munro and Mouritsen, 1996) and recognise 'itself' as the 'I' responsible for the action (Willmott, 1996: 35). If this separation emerges as a precondition of accountability, other elements contribute to shape the accountability of the 'accountable self'. Sinclair (1995: 233) found that the way in which the 'accountable person' internalises and experiences accountability, managing 'language and ideology, values and ethics, emotion and motivation', concurs to shape it. In this regard, a tension challenging accountability depends on the fact that while 'accountability relies on responsibility' the 'self' also has to provide 'answers that make good sense to others' (McKernan, 2012: 
262). For McKernan (2012: 276), this tension is removed when the 'self' conceives accountability not solely as a responsibility but as a duty to provide a gift to the 'other' 'without calculating the return' and 'without reserve'. Similarly, McKernan and MacLullich (2004: 356) argued that the self 'intuition of absolute obligation to the other' is driven by a sense of solidarity that exceeds rationality. That obligation reinforces the authority of the accounting practices. Thus, responsibility is not just a matter of adhering to codes and rules, but it entails an individual ethics that is constructed through the personal relationship with, and the care for, 'others' (Kosmala and McKernan, 2011).

The role of the responsible 'self' and its relationship with 'others' have been explored in the seminal studies of Boland and Schultze (1996) and Roberts (1996). Despite adopting different perspectives, these studies bear similarities and seem to integrate each other in describing the practices through which the 'self' separates or, vice versa, relates with the 'other'. The narrative mode of cognition (Boland and Schultze, 1996) and informal accountability, where lateral, face-to-face communication takes place (Roberts, 1996), enable socialising forms of accountability. In contrast, a calculative, or paradigmatic, mode of cognition (Boland and Schultze, 1996) and 'formal hierarchical accountability' (Roberts, 1996: 40-42) enhance individualising forms of accountability. Despite bearing 'an ineradicable moral dimension' (McKernan and MacLullich, 2004: 328; Roberts and Scapens, 1985), accounting, as a 'codified discourse' (Llewellyn and Milne, 2007) or a 'technique' (Roberts, 1996: 41), aims to provide an objective demonstration of individual achievements, in front of others. Thus, accounting fosters an 'individualised sense of the self' (Roberts, 1996: 55) that becomes subject to external scrutiny and exposed to potential judgements (Roberts, 1996). This visibility bears the risk of limiting the accountability of the 'accountable self' because of the desire to please the 'other', or the fear of failing expectations and being negatively judged (McKernan, 2012; Messner, 2009). Thus, it is the self-attitude for the 'other', and the interdependence between the accountability practices adopted by the 'self', that foster dialogue with the 'other'. Boland and Schultze (1996) criticised Roberts' (1991, 1996) distinction between formal hierarchical accountability and informal accountability as enablers of, respectively, individualising and socialising accountability, highlighting that socialising forms of accountability can also take place in formal hierarchical contexts through a narrative mode. Similar to Boland and Schultze's (1996) perspective, McKernan and MacLullich (2004: 355) saw narratives as completing the 'accounting practice and regulation'; relying on Ricoeur, they explained that 'the ethical force of the narrative conception of identity lies in the fact that it requires us to recognise our identity as being entangled with the identities of the other people'.

This article conceives the accountable person's accountability as 'the capacity and willingness to give explanations for conduct' through an intertwining of narration and calculation (Boland and Schultze, 1996: 62) and 'as something a person is or feels' (Sinclair, 1995: 221). Drawing on the extant literature, this article investigates how Wollemborg, as an 'accountable self', successfully expanded a new organisational model, contributing to solving the credit issues affecting his rural population. The accountability literature served to guide the investigation, moving from the external socioeconomic and biographical elements influencing Wollemborg's actions to an exploration of how Wollemborg himself described his activities and accountability.

\section{Research method}

This historical study was based on archival material, relying on Scott's (1990) quality control criteria for evaluating documentary sources and classifying them with respect to authorship (personal or official) and type of access. The secondary sources (e.g. academic studies, books and biographies) served to select the primary sources, to confirm the interpretation of their content, to gather 
information about the sociohistorical and economical context of that time and to collect information about Wollemborg. The primary sources comprise both documents written by Wollemborg's peers and documents written by, or resulting from the transcripts of discourses made by, Wollemborg himself during the period 1878-1929. The primary sources served to collect information on Wollemborg's activities and to perform a content analysis of his discourses.

The enquiry began by adopting primary and secondary sources to explore the sociohistorical and economic context in which Wollemborg grew up and to describe the credit issues affecting the rural population in the area where Wollemborg's family owned their lands. Moreover, the sources were used to identify previous attempts to solve the credit problem and to describe the core characteristics of rural credit cooperatives. Subsequently, the research was geared at examining Wollemborg's biography and his activity as an accountable 'self'. Initially, the aim was to identify and illustrate those events and connections that may have influenced Wollemborg's decision to take charge of the credit issue affecting the rural population living in his area and to implement a solution to solve the problem by introducing rural credit cooperatives. In this phase, the primary sources served to study the perspectives of influential people of that time and to learn, through the writings of Wollemborg, what he thought about the socioeconomic context, his social status and his mission. This group of primary sources includes eight letters that Wollemborg wrote to Luigi Luzzati (Italian founder of the Schulze-Delitzsch cooperatives) and the extracts of two letters written by Raiffeisen (in the years 1883 and 1884) to Wollemborg. These letters were part of a collection of various writings of Wollemborg published in 2013 by Ecra. As explained by Marconato (1984: 46), most of the letters exchanged between Wollemborg and Raiffeisen have been lost. Therefore, the author of this article considered exclusively the two extracts provided in the book mentioned above.

Subsequently, the study moved to explore Wollemborg's practices and discourses to the members of the rural credit cooperative of Loreggia (that he had founded in 1883, the first in Italy) and to the external potential stakeholders. At this stage, among the primary sources, documents that Wollemborg produced during the period 1883-1889 were selected, with this time frame corresponding to Wollemborg's first term as president of the rural credit cooperative of Loreggia. In this initial period, Wollemborg was the main protagonist of the introduction and expansion of this new organisational model. After 1888, both the environment and the key players changed. In 1888, the Italian rural credit cooperatives were unified under an Italian confederation. In 1890, the Catholic Church founded the first Catholic rural credit cooperative.

The primary sources were analysed through a content analysis aimed at allowing the latent content in the discourses to emerge. The methodological proceedings for undertaking a qualitative content analysis provided by Kohlbacher (2006) were followed as guidelines. The objective of the analysis was to interpret the meaning of the words in relation to the sentences and the whole text. For these reasons, the coding of the texts was carried out manually.

The categories for the coding were deduced from Boland and Schultze (1996) and Roberts (1996). The coding resulted in different units of analysis. The unit of analysis was an individual word within a sentence when searching for the use of the personal pronouns adopted by Wollemborg. The unit of analysis was a paragraph when looking for accounting numbers, and a sentence when searching for explanation of conduct. When searching for individualising forms of accountability, the documents were analysed by searching for accounting data and justification of conduct (through the provision of formal technical rules and data and for discourses where the personal pronoun used by Wollemborg was the first-person singular ' $I$ '). When searching for socialising forms of accountability, the documents were analysed by searching for instances where Wollemborg was giving voice to his stakeholders (narrating situations, experiences, choices and possibilities) or enacting a dialogue with them. The researcher searched also 
for discourses that were stated in the first-person plural ('we'). In addition, the way in which the documentary sources were conveyed to the stakeholders was considered (i.e. transcripts of oral discourses or written documents).

Following Scott's (1990) criteria, Appendix 1 lists all the primary sources written by Wollemborg during the period (1878-1929) and classifies them with respect to authorship (personal or official) and type of access. With the purpose to provide a more detailed information about the document analysed than the reference section, Appendix 1 distinguishes each single discourse and reports, when needed, the title of the collection from which the discourse was extracted. Therefore, when referring to Wollemborg's discourses in the article, the author cites the list in Appendix 1.

\section{Sociohistorical and economic context}

\section{The Italian country}

At the end of the nineteenth century, Italy was a heterogeneous nation, resulting from the union (between 1860 and 1870) of the previous states of the peninsula. Most of the Italian population was illiterate (Daniele and Malanima, 2011) and lived in rural areas. The various regions had different administrative, political and institutional traditions, and 97.6 per cent of the population did not speak the Italian language but many different idioms (Detti and Gozzini, 2000: 272). From an agrarian perspective, despite the differences among the various regions, most of the land was owned by aristocratic landowners and most of the agricultural production was aimed at self-consumption.

\section{The rural population in Veneto}

The Veneto region (northern Italy) had been part of the Italian nation since 1866; its economy was largely based on agricultural activities. The few industries, located in the area of Vicenza, were integrated and harmonised within the predominantly rural context (Lanaro, 1976). The rural population comprised mostly farmers (Lazzarini, 1998). Despite the differences among the various provinces of the Veneto region, poverty was normal. Absent landowners, a lack of investment and the crisis of the 1880s further worsened the situation. In the report prepared for the agrarian inquiry 'Inchiesta Jacini', commissioned by the Italian Parliament, the commissioner for the Veneto region, Emilio Morpurgo (1882), explained that in the province of Padua (where Loreggia is situated), large landed estate was common and small and medium tenants were numerous. Farmers mostly paid rental fees to landowners in kind. The rural farmhouses were humble, and because of poor diet (comprising mostly poor-quality corn) and food shortages, pellagra disease was endemic and particularly common in the area (D'Ancona, 1898; Keller, 1899; Valenti, 1902). The small village of Loreggia had a population of less than 3,000 citizens in 1883; most of these were tenants, with a minority of landowners (Wollemborg, 1883: 3). Loreggia was characterised by highly fragmented landownership, poor soil fertility, the absence of rich landowners and the issue of usury (Ardoino, 1896b: 561). Between 1887 and 1897, the district of Camposampiero (of which the village of Loreggia was part) had the highest annual mean of emigration in the Veneto region (Zalin, 2013: $\mathrm{xvi}$ ). In the second half of the nineteenth century, the city of Padua produced various studies of agricultural economy. Among the researchers, Antonio Keller (1882), leading professor of agriculture at the University of Padua (Soper, 2013), presented an academic discourse in 1882 on the conditions of the rural population and the credit issue in the Veneto region, highlighting how, similarly to Morpurgo, he believed that the entire population (state, provinces, municipalities and private landowners, as well as the poor population) had to cooperate to solve the credit problem (p. 19). 


\section{Credit issue and previous attempts to solve the shortage}

The poor population working in Veneto's rural areas was mostly unable to borrow money from banks, because banks perceived that lending as too risky. These funds were needed by small farmers to face the investments required by the agricultural activity, including the need to buy the seeds to plant before being able to pay for them through the harvest. However, the risks associated to the harvest often resulted in the impossibility for the farmer to repay the debt within the timeline set by banks. This resulted in stagnation, from lack of investment, and in the increasing plague of usury, as this was the main source of finance for poor farmers. Funding was provided by the landowners, pawnshops and usurers. To solve the credit problem, the Austro-Hungarian Empire established saving banks in 1822. However, the commercial, manufacturing and agricultural sectors remained largely excluded from the possible benefits because these institutions directed their support mainly to the public sector (Zalin, 1978). A new attempt to solve the credit problem was undertaken in the 1860 s by a key personality, Luigi Luzzati. Born in Venice on 1 March 1841, Luzzati was initially professor of political economy in Milan, and professor of constitutional law from 1866 at the University of Padua and later at the University of Rome. He was an economist, and a member of the Italian Parliament and the Italian Senate. Understanding the need for a different type of credit institution, Luzzati studied the cooperative organisations abroad and, in 1864, instituted in Lodi (a city of approximately 20,000 inhabitants located in northern Italy), the first urban credit cooperative, based on the German Schulze-Delitzsch model. This type of credit cooperative (located for the most part in urban areas) responded effectively to the financial needs of the middle-class (Zangheri, 1987) and to the wealthy rural population, leaving the credit issue and the plague of usury affecting the poorest part of the rural population unresolved (Lanaro, 1976; Marconato, 1984; Zalin, 2013).

\section{The German credit cooperatives}

In the mid-nineteenth century, two Germans, Hermann Schulze-Delitzsch (1808-1883) and Friedrich Raiffeisen (1818-1888), founded credit cooperatives 'based on the concept of mutual self-help' (Guinnane, 1995; Leonardi, 2012: 54), in Germany, with the aim of providing an answer to the credit problem affecting poor populations excluded from bank loans. In the following years, the two strands of credit cooperative spread throughout Europe. Raiffeisen was inspired by Christian values and had a profound knowledge of the agricultural sector and the issues related to usury. He promoted the establishment of credit cooperatives for rural villages (Zalin, 2013). In contrast to the Schulze-Delitzsch cooperatives, developed in the 1840s, Raiffeisen's cooperatives, which were developed in 1860 s, were purposefully structured to respond to the credit needs of rural society and to solve the issue of usury. The 'Raiffeisen-style cooperatives had only nominal shares and paid no dividends to members; any profits in a business year were placed in a permanent reserve fund' (Banerjee et al., 1994: 502). The loans had different lengths and were easily renewable, and the interest rate was established during the assembly of the members of the cooperative at the start of each year (Zalin, 2013: xxi). Furthermore, Raiffeisen's credit cooperatives were characterised by unlimited liability (Ardoino 1896a: 363). Therefore, in case of the cooperative's failure, 'any creditor could sue any former member for an amount up to the total value of that member's wealth' (Guinnane, 1994: 46). The originating principle of Raiffeisen's credit cooperatives lay in convincing the elites of each village to lead associations of family men, that would have become the cooperative members reciprocally tied by joint responsibility and unlimited liability (Zalin, 2013: xxi). On 20 June 1883, in Loreggia, Wollemborg founded the first rural credit cooperative in Italy, based on Raiffeisen's model. 
In line with Raiffeisen, Wollemborg described the core characteristics of the Italian rural credit cooperatives as unlimited liability, strict limitation to a small geographical area, intangibility of social capital, gratuity of services (only the treasurer was paid), customised long-term loans and absence of stocks and dividends (Wollemborg, 1883). Wollemborg also discussed the German Schulze-Delitzsch credit cooperatives (hereafter, urban credit cooperatives) in various documents and maintained an epistolary communication with the initiator of the Italian urban credit cooperatives, Luigi Luzzati. In a letter dated 30 January 1888, Wollemborg highlighted that the two types of credit cooperative (the one introduced by himself and the one introduced by Luzzati) were different in terms of structural perspective and scope, therefore allowing for their coexistence (Wollemborg, 2013: 149).

\section{Leone Wollemborg}

\section{The accountable self, Leone Wollemborg}

Leone Wollemborg: the early years. Wollemborg, the first of four children, was born in the city of Padua on 4 March 1859 into a rich Jewish family of German origin. His mother's name was Giuseppina Jung. His father, Joseph Wollemborg, graduated in medicine from the University of Padua. However, he never practised medicine as he was an usurer (Marconato, 1984: 28). In 1870, Joseph Wollemborg bought a large country residence (Villa Polcastro) situated in the village of Loreggia, in the province of Padua. Through this acquisition, the Wollemborg family became aristocratic and Joseph Wollemborg, from 1873 until 1876, took an active part, as a council member, in the social life of Loreggia (Marconato, 1984).

Wollemborg received his primary and secondary education from private tutors (Agostini, 1985) and, in 1878 (when he was 19 years old), graduated in law from the University of Padua with a final dissertation titled Dell'autonomia dè comuni ('On the autonomy of municipalities'), which focused on economic and administrative matters related to the territory (Wollemborg, 1878). Wollemborg spent long time in Loreggia, which gave him the opportunity to understand the poor living conditions of the rural population (Zalin, 2013: xv) and befriend personalities of the village, such as the chaplain, the town hall secretary and the doctor (Federazione Veneta delle Banche di Credito Cooperativo, 2014; Marconato, 1984). In this respect, Marconato (1984: 138) reported writings of the doctor of Loreggia explaining Wollemborg's decision to establish the new credit cooperative model in their village as a result of Wollemborg's profound knowledge of the territory, his deep belief of the goodness and usefulness of the new organisation, his affection for the territory and his good heart. After graduating, Wollemborg continued to study economic themes and to discuss these through journal articles. He was active at the local and national level, proposing solutions for social and economic issues of interest to the rural population (Senato della Repubblica, 2016b; Wollemborg, 1891).

Leone Wollemborg: the first rural credit cooperative. In the early 1880s, the writings of Professor Antonio Keller and Alessandro Rossi (Italian Senator from the Veneto region) about the activity of Raiffeisen and the rural credit in Germany influenced Wollemborg's thought. Inspired and supported by these writings, Wollemborg started studying the German credit cooperatives organised by Raiffeisen, with whom he maintained an epistolary communication (Marconato, 1984; Wollemborg, 2013). In a 1884 letter, Raiffeisen wrote to Wollemborg that the credit cooperatives required the elites to intervene in favour of the poor population through unlimited solidarity, constant commitment and without compensation (Wollemborg, 2013: 4). Wollemborg (1884d: 39-54) knew also the agrarian reports prepared by Morpurgo and Jacini (discussed above). He quoted Morpurgo's words that 'the time for doing has come' to highlight the need to solve the credit issues in rural areas (Wollemborg, 1884d: 43). 


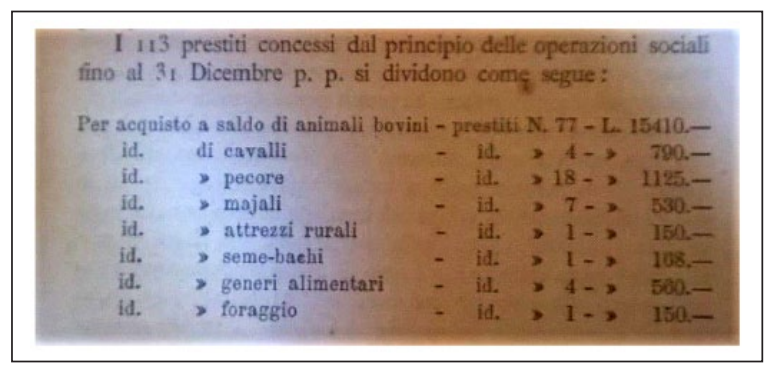

Figure I. Accounting data on the loans.

Source: Data extracted from the annual report of the rural credit cooperative of Loreggia, issued in I885 (Wollemborg, 1885: 4).

Wollemborg started explaining to small landowners, poor farmers and influential people in the village of Loreggia, the reasons and benefits of rural credit cooperatives (Zalin, 2013: xxi-xxii). At the same time, he asked his father to advance him part of his inheritance and, in 1894, he owned approximately 360 land fields in the village of Loreggia. Wollemborg took an active part in the council of Loreggia, initially from 1885 to 1895, and later from 1899 to 1926. Despite not living exclusively in Loreggia, Wollemborg's attachment to the territory and to the living conditions of the local rural population is demonstrated by the fact that, when his son was born, he opened a bank deposit for him and for all the children born in the same year in the village (Marconato, 1984).

On 20 June 1883, the Raiffeisen model was adopted, and the statute of his cooperatives was adapted to the Italian law and the needs and customs of the small village of Loreggia, by Wollemborg. The deed of incorporation of the first rural credit cooperative was registered in the city of Padua on 9 July 1883 (Wollemborg, 1884e). The rural credit cooperative of Loreggia started with 32 members. By December 1883, it included 100 family men, all farmers except Wollemborg himself (landowner and president during the periods 1883-1889 and 1924-1932), the doctor of the village and the town hall secretary (Wollemborg, 1883: 3). On 15 April 1883, the rural credit cooperative of Loreggia started its credit operations with 2,000 Lire (currency) lent by the wealthier citizens of the village (Ardoino, 1896b: 561).

Accountability to members of the rural credit cooperative of Loreggia. Wollemborg's communication with the members of the rural credit cooperative of Loreggia was mainly oral. Formal communication between him, president of the cooperative and the members took place in periodic, mandatory assemblies and at the annual general meeting, transcribed and printed with the annual balance sheet in the annual report. Wollemborg also informally met the members of the cooperative, as they were part of the same small community (Marconato, 1984). As noted above, at the end of the nineteenth century, most of the Italian population were illiterate. In this regard, during a conference in 1884, Wollemborg communicated, as a moral achievement, that 28 members of the cooperative (on 31 December 1883, the rural credit cooperative of Loreggia counted 99 members) had learnt to write their name to sign documents (Wollemborg, 1884d: 52).

During his oral discourses to members, Wollemborg continually provided numerical data and explanations about the types of loans that had been granted during the year, their monetary value, those repaid in full, those still active and their impact. From the minutes of the general meetings of the rural credit cooperative of Loreggia (Wollemborg, 1885, 1986a), it emerged that, in addition to the balance sheet (reported at the end of the internal annual reports), the accounting information was aimed at illustrating how and in what amount money had been lent during the year. As Figure 1 and Table 1 illustrate, farmers asked for loans to buy animals, rural instruments, food and seed. 
Table I. English translation of the data presented in Figure I.

The 113 loans made since the commencement of the cooperative activities, until 3 I December, are as follows:

\begin{tabular}{lcc}
\hline For the purchase of 'items' & No. of loans & Amount of Lire (Italian currency) \\
\hline Cows & 77 & 15,410 \\
Horses & 4 & 790 \\
Sheep & 18 & 1,125 \\
Pigs & 7 & 530 \\
Rural instruments & 1 & 150 \\
Seeds - silkworms & 1 & 168 \\
Food & 4 & 560 \\
Cheese & 1 & 150 \\
\hline
\end{tabular}

Source: Data extracted and translated from the annual report of the rural credit cooperative of Loreggia, issued in 1885 (Wollemborg, 1885: 4).

In addition to disclosing accounting information, Wollemborg provided formal evidence of the results achieved by formally asking influential people of the village to provide feedback (about the cooperative's results) in front of the members of the cooperative. The example below, extracted from Wollemborg (1886a: 2), provides the comment that the archpriest of the village of Loreggia, Don Luigi Tonolo, made during the general meeting of the cooperative, on 28 March 1886, about the economic and 'moral' results of the rural credit cooperative of Loreggia:

One of the cleverest members of the cooperative sold the milk and the cheese, after buying a cow [with the loan of the cooperative]. With those earnings, he was able to keep the calf of the cow for himself. Without the help of the credit cooperative, he would not have obtained this small fortune. (Wollemborg, 1886a: 2)

Wollemborg used to formally separate himself, as president of the cooperative, from other members when highlighting his duties and achievements (as president and founder of the cooperative) or, in contrast, when underlying the benefits obtained and the responsibilities expected by other members. As the example below (Wollemborg, 1885: 1) shows, Wollemborg used the personal pronoun in the first-person singular ('I'; 'me') to highlight his achievements and therefore his reliability as a leader:

$I$ [emphasis added by the author] have been working for two years to set among you the foundation of this society of ours ... You have trusted $m y$ [emphasis added by the author] word and you have been the first ones to follow me [emphasis added by the author]; you should now be legitimately proud. (Wollemborg, 1885: 1)

Wollemborg (1884a) used the second-person singular ('you') to underline the 'other' members' active roles and responsibilities in making decisions affecting the cooperative (p. 226):

You [emphasis added by the author] fixed the limit of loans at Lire 10,000 and today you [emphasis added by the author] decide if it will be convenient to increase it. (Wollemborg, 1884a: 226)

Wollemborg (1885) used the pronoun in the same way to highlight that the future achievements and risks of the organisation would have been the result of the members' actions (p. 6): 
These [future benefits] will depend on you [emphasis added by the author]; they will certainly come if you [emphasis added by the author] will continue in the belief that it is necessary to support each other and that mutual help, honesty and hard work will result not only in tangible rewards, but also in the higher [otherworldly] reward reserved to those who are good and work. (Wollemborg, 1885: 6)

During the general meetings, Wollemborg (1885) shifted from speaking in the first-person singular ('I') to highlight duties and demonstrate his own conduct, to speaking in the first-person plural ('we'; 'our') to share comments, report members' perspectives and expectations, and to highlight obligations and risks as a member of a group of peers. In the example below, Wollemborg (1885: 3) was sharing with all the other members the comments received from one anonymous member. By quoting the exact words of the anonymous member, Wollemborg (1885) was giving voice to the individuals:

In our [emphasis added by the author] small archive we [emphasis added by the author] store, among the various requests for loans, one of a member that stated literally: 'the undersigned member asks for a loan of Liras [Italian currency] ... with the purpose to free myself from usury, at 40 per cent interest rate, that has to be paid in kind in the form of two small cows ...' (p. 3)

In the same way, Wollemborg was using the pronouns ('we'; 'our') to talk about the organisation's achievements that an external observer might have struggled to identify as a cooperative's success. This case is illustrated in the example below where Wollemborg (1884a: 227) highlighted that the most significant results of the cooperative were not reported in balance sheets but evidenced by the improved living conditions of each member's family:

The greater results of our [emphasis added by the author] institution cannot be reported in its balance sheets, as they arise in the economic, moral and intellectual improvements of the population. (Wollemborg, 1884a: 227)

Wollemborg's narrative did not just describe the present but recalled the past, showing how previous collective issues had been resolved. By telling the story of how events evolved, Wollemborg was making visible the results achieved through continuous collaboration and reciprocal support. The sense of group identity as a community of peers facing the same difficulties emerges in the example below where Wollemborg (1884a: 2), who was a landowner, spoke about other landowners as 'them', highlighting to the members of his cooperative (mostly poor farmers) that the past opposition demonstrated by landowners to this form of credit was almost over:

Because these members are tenant farmers, it was asked to the landlords the acknowledgement of their credits. The initial opposition that some of them [landlords] [emphasis added by the author], had manifested is now almost defeated because ... the landowners have understood that they will benefit from the improvement in the life condition of their tenants [emphasis added by the author]. (Wollemborg, 1884a: 2)

Other times, the narration was constructed, and transcribed, as a face-to-face dialogue. As an example, Wollemborg (1884a: 2) was requiring an active participation of the listeners:

Do you [emphasis added by the author] remember how much mistrust, how much scepticism, how many obstacles have we [emphasis added by the author] found on our [emphasis added by the author] path? (Wollemborg, 1885: 1)

It may be concluded that Wollemborg's narrative mode of cognition (Boland and Schultze, 1996) and informal, face-to-face accountability (Roberts, 1996) were pervasive practices, which 
framed and completed the provision of the technical data and accounting information about the activity of the credit cooperative to the members.

\section{Narrating an accountability model}

Replicating the rural credit cooperative model in other villages. By December 1883, Wollemborg had printed and made publicly accessible the charter of the rural credit cooperative of Loreggia, explaining that, through that data accessibility, he was responding to "the many requests coming from every part of Italy and to the kind solicitations of the eminent Professor Keller and other friends' (Leone Wollemborg, 1883: 1). In the years following the establishment of the first rural credit cooperative (in Loreggia), similar institutions were founded in many other villages and small towns outside the Veneto region as well. Wollemborg (1884b) wrote an article, published in Il Raccoglitore (an agricultural bimonthly journal published in the city of Padua), about the two new rural credit cooperatives established after the one in Loreggia. On 20 April 1884, the rural credit cooperative of Cambiano (Tuscany region) was established by local landowners. On 23 April 1884, the rural credit cooperative of Trebaseleghe was founded (Veneto region) by wealthy citizens of the village (a town hall employee, a teacher and a chaplain). On 29 June 1884, the fourth rural credit cooperative was established in Fragnigola, a hamlet in the Veneto region (Wollemborg, 1884d: 112-114). In 1888, all the rural credit cooperatives established in the Italian peninsula were aggregated in a federation. In 1889, after six years, there were 40 rural credit cooperatives in 13 provinces, 27 of which were located in three regions in the northern part of Italy: Veneto, Lombardy and Piedmont (Luzzato, 1932). In 1889, Wollemborg publicly recalled the names of the citizens who had become presidents of the 27 rural credit cooperatives founded in Veneto, Lombardy and Piedmont. These included 21 landowners, three priests, two members of the municipality and a pharmacist (Wollemborg, 1889b: 62).

Narrating an accountability model to external potential members and founders. Wollemborg (1884d) used the term 'promote' (p. 7) to refer to his incessant activity that took place at local, Italian and international levels. His communication means comprised public discourse, conferences (transcribed, printed and published soon after being held) and national and international journal articles. In 1885, Wollemborg founded the monthly journal La Cooperazione Rurale ('The Rural Cooperation'), which actively continued for two decades (Luzzato, 1932). The external potential stakeholders to whom Wollemborg was communicating were the landowners and elites of the cities (who were literate). During a conference, Wollemborg (1884c) listed the following categories: elementary teachers, landowners, people with assets and power, mayors, doctors and priests of the villages. The large number of Wollemborg's conferences was not the result of the impossibility to communicate through written texts, but Wollemborg's willingness to engage in face-to-face communication. Through his constant activity, Wollemborg presented to landowners and the elites of the cities his own experience, explaining why he felt responsible for, and accountable to, the poor population. Wollemborg also described why the credit cooperatives represented the right match for the rural population and why they required the active, disinterested support of the richer part of the population to succeed. Wollemborg (1883) exhorted the elites to drop their traditional apathy, to follow his example and take an active part in the rural credit cooperatives (p. 5). He supported explanations with evidence of the results achieved, sometimes reporting the opinions of the members of the cooperative. For example, at the conference held in Camposampiero on 27 January 1884, Wollemborg reminded to the landowners and to the elites that the issues affecting the rural population were usury, lack of credit, increased poverty, emigration and insufficient support from existing bank institutions. In this case, as during other discourses (Wollemborg, 1883, 
1884c, 1884d: 1-38, 1884d: 39-54, 1886b), Wollemborg explained that unlimited liability was a distinctive characteristic of the type of credit cooperative he established, requiring strictly limited territorial boundaries to foster constant participation, reciprocal support, control and trust among members. Therefore, the rural credit cooperative could not be extended outside the borders of the small villages and its members were asked to actively participate (Wollemborg, 1884e). For example, during that conference Wollemborg (1884c: 9) quoted the exact words of a member of the cooperative. In that sentence (which was not in Italian language, but in the local dialect), the member (a farmer) explained that each of the 100 members controlled each other to ensure that everyone maintained collaborative conduct within the cooperative:

'We are 100 people, who are controlling each other, therefore it is impossible for anyone to not be collaborative', this is what was said to me by a farmer who is a member of the cooperative of Loreggia. In fact, if you multiply by the number of members the quality of individual prudence, you will have ... an enormous amount of incorruptible diligence and indefatigable farsightedness! (Wollemborg, 1884c: 9)

Similarly, Wollemborg publicly shared the richer population's opinion. As the example below illustrates, Wollemborg (1884c: 8-9) publicly acknowledged the elites' doubts by giving voice to them. In this way, he showed empathy and understanding for his peers' preoccupations or doubts:

'How', shouts someone terrified and wealthy, 'should I throw myself in this economic abyss, for the sake of philanthropy, or solely for the love of my neighbour?' It is not a simple challenge to reassure these frightened people, calm the heated shouts, and reply to their objections! (Wollemborg, 1884c: 8-9)

To the external potential members and founders, Wollemborg (1886b: 10) also asked questions about the clarity of the information that he was providing, making them active participants. In a similar way, Wollemborg sometimes used a colloquial tone to thank the audience for their attention and patience:

Despite risking boring the reader [emphasis added by the author], we decided to discuss one by one the criticisms. ... However, isn't our explanation exhaustive, in the opinion of the reader [emphasis added by the author]? (Wollemborg, 1886b: 10)

During his discourses, Wollemborg (1884c: 7) linked unlimited liability with the concept of solidarity and underlined that juridical ability, honesty and morality of each individuals were essential qualities to become part of the cooperative. Moreover, as the objective of the rural credit cooperative was to support the poor, these organisations had to integrate different people, despite census and social class, as peers within the organisation. In the statute of the rural credit cooperative of Loreggia, Wollemborg (1883: 5) underlined that equality of all participants with respect to the duties and the balancing of economic obligations and solidarity between the economically strong and the economically weak members provided the organisation with a highly moral and democratic character. In the same way, while a collaborative attitude among different social classes was desirable, the wealthier part of the population had to be guided by sincere feelings and its actions had to be disinterested (Wollemborg, 1884d: 108). In Wollemborg's opinion, the wealthier part of society could not ask a poor farmer to contribute for money that he did not have. On the contrary, the rich individual should have provided the poor individual with instruments to achieve some sort of benefits (Wollemborg, 2013: 91-107). For this reason, it was not sufficient for the poor farmers to cooperate among themselves. Support and encouragement were needed from the elites (Wollemborg, 2013: 109-127). Awareness of the strong personal co-responsibility and absence of profit incentives characterised the rural credit cooperatives (Wollemborg, 1886b: 7), where the profits accumulated became patrimony owned by the cooperative itself. 
With the same approach adopted to communicate during the rural credit cooperative internal meetings, Wollemborg used the first-person singular 'I' and the first-person plural 'we' also in public conferences when speaking to the landowners and the elites. While sometimes, Wollemborg adopted the personal pronoun 'we', or the possessive pronoun 'our', to address himself and the cooperative of which he was part, in opposition to the 'other' external to the organisation; other times Wollemborg used the pronouns 'we' and 'our' to remark the belonging as a member of the same social group (as a landowner himself). As an example, Wollemborg (1884c: 4) used the possessive pronoun 'our' to recall for his peers that it was their duty, as a powerful and rich social group, to acknowledge the issues affecting the rural population working their own lands and to take an active part in solving the problem. In this way, Wollemborg (1884c) leveraged the sense of collective identity, implicitly asking his peers to stop being passive observers:

You are also aware that ... the small property, which is attacked from every side, will barely survive. The number of expropriations is becoming more frightful every day. You are aware that our [emphasis added by the author] farmers abandon their native country in crowds for other locations, swearing at the ungenerous mother country, because they are exhausted of the inclemency of human beings and nature. (p. 4)

Conversely, Wollemborg spoke in the first-person singular 'I' when justifying his actions or presenting himself as a leading figure that the 'other' (external) people could listen to or follow. As an example, opening a conference, Wollemborg (1884c: 5) spoke in the first-person singular while introducing his role as a leader and ensuring that the governance structure of the rural credit cooperatives was appropriate and naturally fitted to the needs and characteristics of the rural population:

This is the institution $I$ [emphasis added by the author] had the fortune to transplant from the far shores of the Rhine to small Loreggia. Today, dear gentleman, $I$ [emphasis added by the author] have the honour to present it and clarify it to you ...I [emphasis added by the author] would prefer to demonstrate, if you will allow me [emphasis added by the author], how this institution, with slight modifications is appropriate and fit, almost naturally, to the population of our small rural towns, and how, in $m y$ [emphasis added by the author] opinion, the smallest village of these provinces can rise and flourish. (Wollemborg, 1884c: 5)

Given that the target of the rural credit cooperatives was the poor rural population, the length of loans had to be calculated with respect to the needs of this sector. The short-term loans last two years, while the long-term ones could be extended up to 10years. Replying to criticisms about the structural characteristics of the rural credit cooperatives, Wollemborg (1886b) highlighted how rural credit cooperatives supplemented local money largely by collecting capital from the bigger cities, private investors and institutions that were looking for long-term, safe investments and moderate returns ( $\mathrm{p}$. 4). Finally, as rural credit cooperatives were not a charity, individuals must not be part of any charitable congregation to become a member (Wollemborg, 1884d: 75-86, 1884e). In 1887, Wollemborg published, in the Italian Economic Journal ('Giornale degli Economisti'), an article titled 'La teorica della cooperazione' ('The theory of the cooperation'), in which he discussed the concept of cooperation and distinguished the cooperative form of association from both speculative associations and charities. As he explained, cooperative organisations were associations of consumers or sellers facing a common need and developing internal transactions to obtain different personal advantages.

To the external stakeholders, Wollemborg made also available the rural credit cooperative internal reports. For example, in the year 1889, Wollemborg was invited to the Exposition Universelle de Paris ('Universal Expo of Paris'), where his project of introducing the rural credit cooperatives received the gold medal. In that occasion, Wollemborg provided evidence of the benefits produced by rural credit cooperatives by publicly reporting accounting information and data on the members of 27 rural credit cooperatives. Therefore, he effectively extended his accountability through extended 


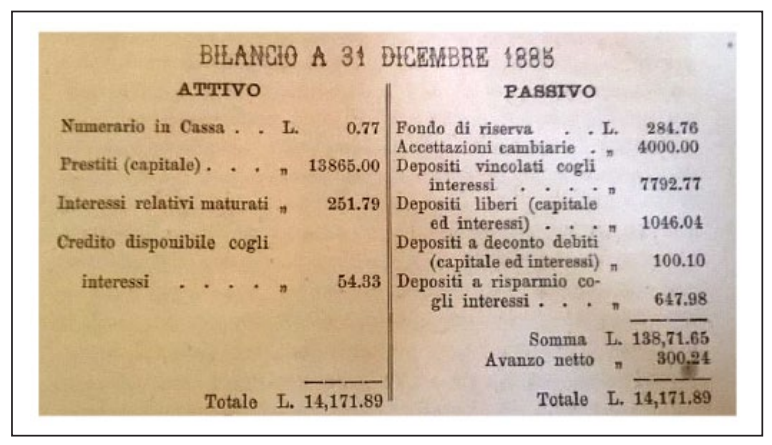

Figure 2. Internal reporting.

Source: Data extracted from 'Summary of the general meeting with the members and Annual Report 1885' (Wollemborg, 1886a: 7).

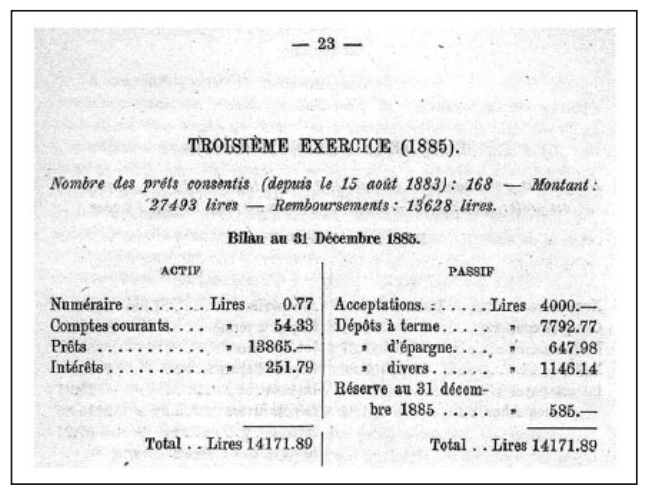

Figure 3. Making publicly available the internal reporting.

Source: Data extracted from 'Les Caisses Rurales Italiennes - Rapport pour l'Esposition Universelle de Paris en 1889' (Wollemborg, 1889b: 23). The accounts provided in this picture are the same as those provided in Figure 2 (Wollemborg, 1886a).

means to broaden the adoption of cooperatives for social advancement purposes. The printed version of that conference (a book of 60 pages) contains:

- an introductory section;

- a description of the organisational structure of a rural credit cooperative;

- financial statements and a brief description of each of 27 rural credit cooperatives founded in Veneto until 1887, with the balance sheets reported for each rural credit cooperative representative of each year of activity;

- four summary tables, which recorded for each of the 27 organisations the following: (a) general information (such as the president's name and the number of members), (b) the members' classification by income, (c) the members' classification by type of loan and (d) the cash flow statements and balance sheets.

The balance sheets reported in Figure 2 come from the annual report of the rural credit cooperative of Loreggia and those reported in Figure 3 are extracted from the book presented at the Expo 
in Paris, respectively. A comparison between Figures 2 and 3 demonstrates how Wollemborg reported the same information, contained in the annual report of the cooperative of Loreggia, at the Expo in Paris, translated in French.

While publicly reporting the accounting data to external stakeholders, Wollemborg highlighted that the financial statements could not provide a comprehensive picture of all the beneficial effects that rural credit cooperatives had produced for the rural population (Wollemborg, 1884d: 1-38). He shared this opinion with members of his cooperative. Wollemborg integrated the accounting numbers by telling the story of the cooperatives' achievements from the beginning until the present time. For example, Wollemborg (1886b: 9) recalled the past 30 years of successful activity of the rural credit cooperatives in Germany:

We put forward the ample and splendid evidence of Germany: over 30 years of [rural credit cooperative] experience, hundreds and hundreds of [credit cooperative] implementations, with constantly positive effects recorded in private and public reports. (Wollemborg, 1886b: 9)

These examples demonstrate how Wollemborg's accountability discourses and practices, when talking to the external potential members and founders of new rural credit cooperatives, were very similar to his discourses to the members of the rural credit cooperative of Loreggia. The analysis of Wollemborg's narrative shows how he was feeling and acting as an 'accountable self' with the aim of broadcasting this model of accountability to external potential founders of new rural credit cooperatives.

\section{Leone Wollemborg: international recognition for his work}

While Wollemborg's activities and achievements were described in journal articles (Comizio Agrario di Padova, 1884; Editorial, 1884), his discourses were printed in the main European languages, and in September 1889, his project received the gold medal at the Exposition Universelle de Paris (Zalin, 2013: xxiii). Remembering Wollemborg's activities in the rural credit cooperatives a few years after Wollemborg's death, Professor Luzzato (1932) used the words 'amorous surveillance for their [of the rural credit cooperatives] development, tireless care for providing the best legislative protection [to the cooperative members]' (p. 822).

Wollemborg's activities were recognised almost immediately after the establishment of the rural credit cooperative of Loreggia. Two examples are extracted from two articles published in the journal Il Raccoglitore. Editorial (1884) recalled tours and conferences to which Wollemborg was invited. The Comizio Agrario di Padova (1884: 201) highlighted how, after the establishment of the rural credit cooperative of Loreggia, 'praise and encouragement came [to Wollemborg] from every part of Italy (and from outside) for continuing with his activity'.

In addition, Wollemborg fulfilled a relevant role at the national level. In 1888, he was founder and president of the Federation of the Italian Rural Credit Cooperatives. He was a member of the Italian Parliament from 1892 to 1909, Minister of Finance (in the Zanardelli Cabinet) in 1901 and a member of the Italian Senate from 1914 (Senato della Repubblica, 2016a). During his parliamentary activity, he worked with 'expertise and strength' (Foà, 1935: 806) to promote legislative changes in favour of Italian rural areas, taking care of issues related to public finances, credit and social policies. From 1915 to 1918, Wollemborg was president of the public assistance of Rome. He did not adhere to the fascism and he opposed the control of personal freedom. His extraordinary activity was recognised immediately after his death at the Italian (see Foà, 1935; Luzzato, 1932) and international levels. For example, Wollemborg's work received the following words of praise in the Economic Journal: 
In the 'eighties [of the 19th century] he [Wollemborg] threw himself with great vigour in to the study of consumers' co-operation, and of co-operative credit institutions, on the Raiffeisen model, in rural areas. And he did much to popularise and multiply such institutions in his native Veneto. (Dalton, 1935: 549)

In 1901 he [Wollemborg] become Minister of Finance in the Cabinet of Zanardelli, and prepared an ambitious scheme for the reform of taxation, both national and local ... Wollemborg was of a type ... combining theoretical interests with practical activities, and carrying expert knowledge in public life ... In his abortive project of financial reform in 1901, Wollemborg was in advance of his time. Some of his ideas, which were then rejected, have since been adopted. (Dalton, 1935: 550)

\section{Discussion and conclusion}

\section{Synthesis: the accountable self and the social context}

At the end of the nineteenth century, the small village of Loreggia had the characteristics of a culturally homogeneous society, where the population was mostly occupied in the same activity (agriculture), shared the same poor living conditions and everyone knew each other personally. The rich landowners, often living in the big cities and frequently absent from their lands, represented a different powerful social group. Wollemborg, an economist, a philanthropist and a landowner, was part of these elites and he felt responsible for the dreadful economic conditions of the rural population and believed that it was the duty of the elites to solve credit and usury issues. To achieve this, in 1883, Wollemborg introduced the first rural credit cooperative (Raiffeisen-style) in the village of Loreggia where he was landowner. From that moment onward, he worked to expand this cooperative model throughout Italy. The success of Wollemborg's activity (Dalton, 1935; Leonardi, 2012; Luzzato, 1932; Marconato, 1984; Zalin, 2013) was evident from the initial stage (1883-1889) of promotion of the rural credit cooperatives in Italy, where he was a leading figure. In 1889, six years after the introduction of the first rural credit cooperative in the village of Loreggia, there were 40 rural credit cooperatives in 13 provinces, 27 of which were in Veneto, Lombardy and Piedmont regions (Luzzato, 1932). In 1889, Wollemborg's project of introducing the rural credit cooperatives received the gold medal at the Exposition Universelle de Paris (Zalin, 2013: xxiii). In the years after, other powerful actors, following his example, positively contributed to further expand these cooperatives (Leonardi, 2012; Luzzato, 1932). The explanation behind Wollemborg's decision to become accountable to the poor farmers in his territory emerges from the study of his biography and the related socioeconomic context. Explanations include factors such as the family's Jewish and aristocratic origins, the usury practice of his father, his university background, his concerns for the economic issues affecting the territory, his empathy and his professional friendships. From the study of Wollemborg's activities, it is evident that after the establishment of the first rural credit cooperative in Loreggia (of which he was president), Wollemborg worked tirelessly not only to support the poor farmers but also to narrate his accountability experience to the external wealthy members of the population. Wollemborg was aware that the elites' behaviour was among the main causes of increasing poverty in rural areas. At the same time, he was aware that the elites were the only social group with the economic and political power to change that situation (Wollemborg, 1883, 1884c, 1884d). The rural credit cooperatives leveraged specific aspects of accountability, for which the wealthier part of the society was identified as the initial promoter and the future leader of these cooperatives. Wollemborg urged landowners to avoid being absent and to take an active role in solving the agrarian issue (Wollemborg, 2013: 91107) by following his example (Wollemborg, 1884b). 


\section{Synthesis: narrating the self-accountability}

The success of Wollemborg's activities is not limited to being accountable to the 'other' as members of the rural credit cooperative of Loreggia. To solve usury and credit issues affecting the rural population, he decided to publicly narrate to the 'others as putative members' (Munro and Mouritsen, 1996), his way of 'being accountable'. The findings of this study demonstrate that his activity was not a simple promotion of a new organisational model and that Wollemborg's discourses and practices were very similar among the two groups of stakeholders (members of the rural credit cooperative of Loreggia and external potential financers and funders of new cooperatives, such as wealthy citizens/landowners). By publicly narrating how and why he was accountable to the 'other', Wollemborg provided, to the potential 'other', the elites, an example to follow. Each of them could have been an alter ego of 'Wollemborg' in their own villages. In addition, by integrating narratives with accounting practices and taking personal responsibility for his own choices (Boland and Schultze, 1996; Roberts, 1996), Wollemborg enhanced trust and engagement of the external observers because he was providing tangible proofs of his achievements.

Moreover, as demonstrated above, Wollemborg adopted the same communicative forms when he was speaking as president of the rural credit cooperative of Loreggia and when he was talking as a promoter of this new organisational model. Complete disclosure of the balance sheet of the rural credit cooperative of Loreggia were provided, not only to members of the organisation (entitled to receive them) but also to the wider public. Wollemborg separated himself from 'others' (either internal members of the rural credit cooperative of Loreggia or 'external potential stakeholders', such as wealthy citizens/landowners) to underline his responsibility and achievements as a leader (speaking in the first-person singular 'I'). Similarly, he integrated a 'narrative mode of cognition' (Boland and Schultze, 1996), informal, face-to-face accountability (Roberts, 1996) when speaking in the plural voice, highlighting shared identity and ties. Analysis of Wollemborg's discourses showed that he was continuously telling the story of the organisation and disclosing to all stakeholders the needs, achievements, questions and opinions of all the 'others'. The result was an intertwining of individualising and socialising forms of accountability, where the practices of socialising accountability (Boland and Schultze, 1996; Roberts, 1996) framed the accounting information and permeated all Wollemborg's communication. By narrating his being an 'accountable self' and 'telling the story' of the members and the organisation activity to a wider public, Wollemborg enhanced trust and engagement between the 'self' and the 'other'.

\section{Contribution to the literature and concluding remarks}

The relevance of undertaking historical studies has been underlined by Ritson and Parker (2016), Parker (2015), Guinnane (2011) and Gomes et al. (2011), demonstrating from different perspectives how the past holds lesson for the present. By exploring how a landowner and founder of a new organisational model narrated his way of being an 'accountable self' to solve the credit issue affecting his rural population, this study adds to the accounting history literature and the accountability literature in historical contexts. This study also contributes to previous biographical works by providing examples of individuals who, through their actions, made a difference in their own context. While previous studies exploring the 'first' concentrate on initiators' biographies and activities in the accounting field (Carnegie et al., 2000; Carnegie and Williams, 2001; Clarke, 2005; Cooper, 2008; Parker, 2014; Romeo and Rigsby, 2008), this article illustrates how the initiator of a new organisational model successfully achieved his objective by narrating his way of being an 'accountable self' to external potential stakeholders. 
In addition, by focusing specifically on the 'accountable self' attitude and explanations to the 'other', this work adds to the social impact of accounting by exploring how accounting (Abeysekera, 2005; Barnes, 2007; Chandler, 2016; Fülbier and Klein, 2015; Platonova, 2009; Sokolov, 2015; Walker, 2008) and accountability (Antonelli et al., 2017; Evans and Pierpoint, 2015; Fowler and Cordery, 2015; Jacobs and Walker, 2004; Killian, 2015; Oakes and Young, 2008; Rammal and Parker, 2012; Sargiacomo and Gomes, 2011) are shaped by, and shape, context and social relations.

It has been shown that narratives were used to manage stakeholders' impressions (Evans and Pierpoint, 2015) and discursively explain choices not only to the 'others' but also to rationalise the 'self' (Oakes and Young, 2008: 786). This study demonstrates that, by narrating his own way of being responsible to a potential 'other' and making a pervasive use of face-to-face narrative accountability, Wollemborg bridged the gap and obtained the trust and engagement of external potential members and future leaders of cooperatives. Thus, this study contributes to an understanding of the relevance for initiators of new organisational models to act as 'accountable selves'. In addition, as emerged in Oakes and Young (2008), also in this study, the 'accountable person' used accountability to empower the community and not solely to satisfy his stakeholders' expectations.

The findings demonstrate that while narrative and socialising forms of accountability enhance dialogue (Boland and Schultze, 1996; Oakes and Young, 2008; Roberts, 1996), it is the individual willingness to become accountable to the 'other' that represents the prerequisite of enabling a trustful, unlimited accountability. While Messner (2009: 918) described the 'accountable self' as 'limited in its ability to give an account of itself' to the 'other', this article, in line with McKernan and MacLullich (2004), showed that when the 'self' identifies itself as linked to the 'other' by deep bonds, this shared identity allows the 'self' to override the fear for potential negative judgement or damage of personal interests because the collective good is valued more. Wollemborg felt an 'ethical impulse' and an 'absolute obligation' (McKernan and MacLullich, 2004: 356) to put his economic knowledge and power at the service of the 'other'. However, he was not naïve: Wollemborg's accountability was driven by the rational interest of solving the credit issue. As he explained, improving poor farmers' economic conditions, without expecting economic returns, was not only the responsibility of the wealthy individuals but a more general ethics obligation to enhance social cohesion, refrain young generations from emigration and ultimately ensure the landowners' income. Despite the changed context and population needs, Wollemborg's lesson is still valid nowadays.

Ultimately, what emerges from this study is that the successful expansion of rural credit cooperatives was not solely a matter of matching social context with organisational characteristics, but it was related to the ethical attitude of the 'accountable self', a sense of identity and a profound responsibility, leading him to make a pervasive use of face-to-face narrative accountability. When 'being held accountable' is not perceived as a risk but as an opportunity, narrating the self-responsibility may become the key to collective success.

\section{Authors' Note}

Eleonora Masiero is now affiliated with Ca' Foscari University of Venice, Venice, Italy.

\section{Acknowledgements}

The author wishes to thank the anonymous reviewers for their helpful guidance in shaping the final article, the editors, the participants at the tenth Accounting History Symposium in Adelaide in 2017 and the participants at the ninth Accounting History International Conference in Verona in 2017 for their useful comments. The author also wishes to thank Enrico Bracci, Carolyn Fowler, Carlo Fumian, Alessandro Lai, Giulia Leoni, 
Laura Maran, Lee Parker and Riccardo Stacchezzini for their insightful and constructive comments. Special thanks to Garry Carnegie and Niamh Brennan for their invaluable assistance. All errors are the responsibility of the author alone.

\section{Funding}

The author received no financial support for the research, authorship, and/or publication of this article.

\section{ORCID iD}

Eleonora Masiero iD https://orcid.org/0000-0001-6289-1820

\section{References}

Primary Sources

Ardoino P (1896a) Le casse rurali di prestiti. Rivista Internazionale di Scienze Sociali e Discipline Ausiliarie 10(39): 353-366.

Ardoino P (1896b) Le casse rurali di prestiti. Rivista Internazionale di Scienze Sociali e Discipline Ausiliarie 10(40): 553-570.

Comizio Agrario di Padova (1884) Atti ufficiali del comizio agrario di Padova. Relazione dell'operato della direzione del comizio durante l'anno 1883. Il Raccoglitore 7(12): 201-205.

Dalton H (1935) Review. The Economic Journal 45(179): 549-550.

D'Ancona N (1898) Relazione del signor presidente Comm. Dott. Napoleone D'Ancona sugli esiti delle locande sanitarie e sugli esiti della gestione della commissione provinciale permanente contro la pellagra. Padua: Stab. Tip. Prov. Ditta L. Penada

Editorial (1884) Cassa di prestiti - conferenza in Villafranca padovana. Il Raccoglitore 7(13):225-226.

Foà B (1935) Review. Giornale degli Economisti e Rivista di Statistica 75(9): 805-806.

Keller A (1882) Le Condizioni dei Contadini nel Veneto e le Associazioni delle Casse di Anticipazione. Milan: Tipografia Lodovico Felice Cogliatti.

Keller A (1899) La Pellagra. Padua: Tipografia Gio. Batt. Randi.

Luzzato F (1932) Economia e finanza nell'opera di Leone Wollemborg. Giornale degli Economisti e Rivista di Statistica 72(11): 820-834.

Morpurgo E (1882) Atti della Giunta per la Inchiesta Agraria e sulle Condizioni della Classe Agricola, vol. 4. Rome: Forzani e C. Tipografi del Senato.

Senato della Repubblica (2016a) Scheda senatore Wollemborg Leone. Available at: http://notes9.senato.it /Web/senregno.nsf/bf3405efdc879699c125785d0059d033/732678e197372e964125646f0061911f?Ope nDocument\# (accessed 14 July 2016).

Senato della Repubblica (2016b) Scheda senatore Wollemborg Leone (Fascicolo personale). Available at: http://notes9.senato.it/web/senregno.nsf/All/732678E197372E964125646F0061911F/\$FILE/2346\%20 Wollemborg\%20Leone\%20fascicolo.pdf (accessed 14 July 2016).

Valenti G (1902) Cooperazione Rurale. Florence: Barbèra.

Wollemborg L (1878) Dell'autonomia dè comuni. Dissertazione dottorale. PhD Thesis, Archive of the Department of Law, University of Padua, Padua, Italy.

Wollemborg L (1883) La Prima Cassa Cooperativa di Prestiti Secondo il Sistema Raiffeisen in Italia. Padua: Stabilimento Tip. Ditta L. Penada.

Wollemborg L (1884a) Cassa cooperativa di prestiti di Loreggia - relazione del presidente dott. Leone Wollemborg all'assemblea generale de' soci del 26 Marzo 1884. Il Raccoglitore 7(13): 226-227.

Wollemborg L (1884b) Due nuove casse di prestiti. Il Raccoglitore 7(13): 222-223.

Wollemborg L (1884c) Le casse cooperative di prestiti. In: Conferenza detta il 27 Gennaio 1884 all 'Associazione Magistrale di Camposampiero. Padua: Stab. Tip. Prov. Ditta L. Penada.

Wollemborg L (1884d) L'ordinamento delle casse dei prestiti. In: Conferenza detta il 24 Novembre 1884 all'Associazione Agraria Friulana; Aggiuntovi lo Statuto d'una Cassa di Prestiti; lo Statuto d'un Circolo Agricolo e altri Scritti dell'Autore. Verona, Padua: Drucker \& Tedeschi.

Wollemborg L (1884e) Stimolare le energie morali assopite. Il Raccoglitore 7(13): 226-227. 
Wollemborg L (1885) Cassa di Prestiti di Loreggia Relazioni del Presidente e dei Sindaci e Bilancio 1884. Padua: Stab. Tip. Ditta L. Penada.

Wollemborg L (1886a) Cassa di Prestiti di Loreggia Relazioni del Presidente e dei Sindaci e Bilancio 1885. Padua: Stab. Tip. Prov. L. Penada.

Wollemborg L (1886b) Extract from: Cooperazione Rurale 15 Agosto 1886. In: Manuale per le Banche Popolari Italiane. 2nd edn. Milan: E. Reggiani e c.

Wollemborg L (1887) La teorica della cooperazione. Giornale Degli Economisti 2(2): 129-144.

Wollemborg L (1889a) Il più antico esempio dell'assicurazione contro i danni della mortalità del bestiame. Giornale Degli Economisti 4(1): 67-69.

Wollemborg L (1889b) Les Caisses Rurales Italiennes. Rapport pour l'Exposition Universelle de Paris en 1889. Rome: Istituto Cartografico Italiano.

Wollemborg L (1891) La situazione finanziaria. Giornale Degli Economisti 3(2): 166-175.

Wollemborg L (2013) 'Il sentimento del bene comune'. Scritti e discorsi scelti del fondatore della prima Cassa Rurale italiana (1883-1929). Rome: Ecra.

\section{Secondary Sources}

Abeysekera I (2005) Accounting: In crisis or ascendancy? Accounting History 10(3): 71-87.

Agostini F (1985) Leone Wollemborg (1859-1934) pioniere del credito agrario. In: Zalin G (ed.) Un Secolo Di Cooperazione Di Credito Nel Veneto. Le Casse Rurali Ed Artigiane 1883-1983. Limena, Padua: Signum, pp. 17-40.

Antonelli V, D'Alessio R, Rossi R and Cafaro EM (2017) Accounting in hybrid forms of capitalist/socialist enterprises: A multiple interpretative approach to the Royal Factory of Silk of San Leucio, 1802-1826. Accounting History 22(3): 274-300.

Banerjee AV, Besley T and Guinnane TW (1994) The neighbor's keeper: The design of a credit cooperative with theory and a test. The Quarterly Journal of Economics 109(2): 491-515.

Barnes P (2007) Minsky's financial instability hypothesis, information asymmetry and accounting information: The UK financial crises of 1866 and 1987. Accounting History 12(1): 29-53.

Boland RJ and Schultze U (1996) Narrating accountability: Cognition and the production of the accountable self. In: Munro R and Mouritsen J (eds) Accountability: Power, Ethos and the Technologies of Managing. London: International Thomson Business Press, pp. 62-81.

Bovens M (2010) Two concepts of accountability: Accountability as a virtue and as a mechanism. West European Politics 33(5): 946-967.

Carnegie GD and Williams BG (2001) The first professors of accounting in Australia. Accounting History 6(1): 103-115.

Carnegie GD, Parker RH and Wigg R (2000) The life and career of John Spence Ogilvy (1805-71), the first chartered accountant to emigrate to Australia. Accounting, Business \& Financial History 10: 371-383.

Chandler RA (2016) Questions of ethics and etiquette in the society of accountants in Edinburgh, 1853-1951. Accounting History 22(2): 179-192.

Clarke P (2005) The story of Bernard F. Shields: The first professor of accountancy in the UK. Accounting History 10(2): 103-123.

Cooper K (2008) Mary Addison Hamilton, Australia's first lady of numbers. Accounting History 13(2): 135-161.

Daniele V and Malanima P (2011) Il Divario Nord-sud in Italia 1861-2011. Italy: Rubbettino.

Detti T and Gozzini G (2000) Storia Contemporanea I. L'ottocento. Milan: Bruno Mondadori.

Evans L and Pierpoint J (2015) Framing the Magdalen: Sentimental narratives and impression management in charity annual reporting. Accounting and Business Research 45(6-7): 661-690.

Federazione Veneta delle Banche di Credito Cooperativo (2014) Leone Wollemborg. Il Sentimento Del Bene Comune [Leone Wollemborg. The perception of the common good]. Available at: https://www.youtube. com/watch?v=2KKJhMfU9GA (accessed 13 October 2014)

Fowler CJ and Cordery CJ (2015) From community to public ownership: A tale of changing accountabilities. Accounting, Auditing \& Accountability Journal 28(1): 128-153.

Fülbier RU and Klein M (2015) Balancing past and present: The impact of accounting internationalisation on German accounting regulations. Accounting History 20(3): 342-374. 
Giddens A (1984) The Constitution of Society. Outline of the Theory of Structuration. Berkeley, CA: University of California Press.

Gomes D, Carnegie GD, Napier CJ, Parker LD and West B (2011) Does accounting history matter? Accounting History 16(4): 389-402.

Guinnane TW (1994) A failed institutional transplant: Raiffeisen's credit cooperatives in Ireland, 1894-1914. Explorations in Economic History 31(1): 38-61.

Guinnane TW (1995) Diversification, liquidity and supervision for small financial institutions: Nineteenthcentury German credit cooperatives. Center Discussion Paper no. 733. Economic Growth Center, Yale University. Available at: https://www.econstor.eu/bitstream/10419/160650/1/cdp733.pdf

Guinnane TW (2011) The early German credit cooperatives and microfinance organizations today: Similarities and differences. In: Armendáriz B and Labie M (eds) The Handbook of Microfinance. Singapore: World Scientific Publishing, pp. 77-100.

Jacobs K and Walker SP (2004) Accounting and accountability in the Iona Community. Accounting, Auditing \& Accountability Journal 17(3): 361-381.

Killian S (2015) 'For lack of accountability': The logic of the price in Ireland's Magdalen Laundries. Accounting, Organizations and Society 43: 17-32.

Kohlbacher F (2006) The use of qualitative content analysis in case study research. Forum Qualitative Sozialforschung/Forum: Qualitative Social Research 7(1): 21.

Kosmala K and McKernan JF (2011) From care of the self to care for the other: Neglected aspects of Foucault's late work. Accounting, Auditing \& Accountability Journal 24(3): 377-402.

Lanaro S (1976) Società e ideologie nel Veneto rurale (1866-1898). Rome: Edizioni di Storia e Letteratura.

Lazzarini A (1998) Fra Tradizione e Innovazione. Studi su Agricoltura e Società Rurale nel Veneto dell'Ottocento. Milan: FrancoAngeli Storia.

Leonardi A (2012) Italian credit cooperatives from 1918 to 1945. The Journal of European Economic History 41(2): 51-81.

Llewellyn S and Milne MJ (2007) Accounting as codified discourses. Accounting, Auditing \& Accountability Journal 20(6): 805-824.

McKernan JF (2012) Accountability as aporia, testimony, and gift. Critical Perspectives on Accounting 23(3): $258-278$.

McKernan JF and MacLullich KK (2004) Accounting, love and justice. Accounting, Auditing \& Accountability Journal 17(3): 327-360.

Marconato R (1984) La figura e l'opera di Leone Wollemborg. Il fondatore delle casse rurali nella realtà dell'Ottocento e del Novecento. Treviso: La vita del popolo.

Messner M (2009) The limits of accountability. Accounting, Organizations and Society 34(8): 918-938.

Munro R and Mouritsen J (1996) Accountability: Power, Ethos and the Technologies of Managing. London: International Boston Business Press.

Oakes LS and Young JJ (2008) Accountability re-examined: Evidence from Hull House. Accounting, Auditing \& Accountability Journal 21(6): 765-790.

Parker LD (2015) Accounting historiography: Looking back to the future. Meditari Accountancy Research 23(2): $142-157$.

Parker RH (2014) The first 32 importers of an English professional accountancy qualification: Opportunities, incentives, impact. Accounting History 19(1-2): 171-192.

Platonova NV (2009) Peter the Great's government reforms and accounting practice in Russia. Accounting History 14(4): 437-464.

Rammal HG and Parker LD (2012) Islamic banking in Pakistan: A history of emergent accountability and regulation. Accounting History 18(1): 5-29.

Ritson PA and Parker LD (2016) You're in the Army now! Historical lessons for contemporary management theorists. Journal of Management History 22(3): 320-340.

Roberts J (1991) The possibilities of accountability. Accounting, Organizations and Society 16(4): 355-368.

Roberts J (1996) From discipline to dialogue: Individualizing and socializing forms of accountability. In: Munro R and Mouritsen J (eds) Accountability: Power, Ethos and the Technologies of Managing. London: International Boston Business Press, pp. 40-61. 
Roberts J and Scapens R (1985) Accounting systems and systems of accountability-Understanding accounting practices in their organizational contexts. Accounting, Organizations and Society 10(4): 443-456.

Romeo G and Rigsby JT (2008) Disseminating professionalism: The influence of Selden Hopkins on the USA accounting profession. Accounting History 13(4): 415-450.

Sargiacomo M and Gomes D (2011) Accounting and accountability in local government: Contributions from accounting history research. Accounting History 16(3): 253-290.

Scott J (1990) A Matter of Record: Documentary Sources in Social Research. Cambridge: Polity Press.

Sinclair A (1995) The chameleon of accountability: Forms and discourses. Accounting, Organizations and Society 20(2-3): 219-237.

Sokolov V (2015) A history of professional accounting societies in St Petersburg. Accounting History 20(3): $375-395$.

Soper SC (2013) Building a Civil Society: Associations, Public Life, and the Origin of Modern Italy. Toronto, ON, Canada: University of Toronto Press.

Walker SP (2008) Accounting, paper shadows and the stigmatised poor. Accounting, Organizations and Society 33: 453-487.

Willmott H (1996) Thinking accountability: Accounting for the disciplined production of self. In: Munro $\mathrm{R}$ and Mouritsen J (eds) Accountability: Power, Ethos and the Technologies of Managing. London: International Boston Business Press, pp. 23-39.

Zalin G (1978) La Società Agraria Veneta Del Secondo Ottocento. Possidenti E Contadini Nel Sottosviluppo Regionale. Padua: CEDAM.

Zalin G (2013) Da Raiffeisen a Wollemborg: le origini del piccolo credito nelle campagne. In: Wollemborg L (ed.) 'Il sentimento del bene comune'. Scritti e discorsi scelti del fondatore della prima Cassa Rurale italiana (1883-1929). Rome: Ecra, pp. ix-xxviii.

Zangheri R (1987) Nascita e primi sviluppi. In: Zangheri R, Galasso G and Castronovo V (eds) Storia del Movimento Cooperaivo in Italia 1886-1986. Turin: Giulio Einaudi Editore, pp. 5-216.

Appendix I. Primary sources written by Leone Wollemborg.

\begin{tabular}{|c|c|c|c|}
\hline $\begin{array}{l}\text { List of the primary sources (in chronological } \\
\text { order) }\end{array}$ & Access & Authorship & Notes on the source \\
\hline $\begin{array}{l}\text { Wollemborg L ( } 1878 \text { ) Dell'autonomia } \\
\text { dè comuni. Dissertazione dottorale. PhD } \\
\text { Thesis, Archive of the Department of Law, } \\
\text { University of Padua, Padua, Italy. } \\
\text { From: University of Padua Library }\end{array}$ & $\begin{array}{l}\text { Open } \\
\text { Archival }\end{array}$ & $\begin{array}{l}\text { Private } \\
\text { Official }\end{array}$ & \\
\hline $\begin{array}{l}\text { Wollemborg L (I883) La Prima Cassa } \\
\text { Cooperativa di Prestiti Secondo il Sistema } \\
\text { Raiffeisen in Italia. Padua: Stabilimento Tip. } \\
\text { Ditta L. Penada. } \\
\text { From: Padua Public Library, Padua }\end{array}$ & $\begin{array}{l}\text { Open } \\
\text { Published }\end{array}$ & $\begin{array}{l}\text { Private } \\
\text { Official }\end{array}$ & \\
\hline $\begin{array}{l}\text { Wollemborg L (1883) La Prima Cassa } \\
\text { Cooperativa di Prestiti Secondo il Sistema } \\
\text { Raiffeisen in Italia. In: Wollemborg L (2013) ‘ll } \\
\text { sentimento del bene comune’. Scritti e discorsi } \\
\text { scelti del fondatore della prima Cassa Rurale } \\
\text { italiana (I883-1929). Rome: Ecra, pp. 3-20. }\end{array}$ & $\begin{array}{l}\text { Open } \\
\text { Published }\end{array}$ & $\begin{array}{l}\text { Private } \\
\text { Official }\end{array}$ & $\begin{array}{l}\text { In comparison with the other } \\
\text { version of the document reported } \\
\text { above (Wollemborg, I 883), in } \\
\text { this version, two letters between } \\
\text { Raiffeisen and Wollemborg are } \\
\text { included in the footnotes }\end{array}$ \\
\hline $\begin{array}{l}\text { Wollemborg L ( } 1884 \text { a) Cassa cooperativa } \\
\text { di prestiti di Loreggia - relazione del } \\
\text { presidente dott. Leone Wollemborg all }\end{array}$ & $\begin{array}{l}\text { Open } \\
\text { Archival }\end{array}$ & $\begin{array}{l}\text { Private } \\
\text { Official }\end{array}$ & $\begin{array}{l}\text { This text was reported in the } \\
\text { journal II Raccoglitore by the } \\
\text { editor of the journal }\end{array}$ \\
\hline
\end{tabular}

'assemblea generale de' soci del 26 Marzo

1884. II Raccoglitore 7(13): 226-227.

From: University of Padua Library 
Appendix I. (Continued)

List of the primary sources (in chronological Access Authorship Notes on the source order)

Wollemborg L (1884b) Due nuove casse di prestiti. II Raccoglitore 7( I3): 222-223.

From: University of Padua Library

Wollemborg L (1884c) Le casse cooperative di prestiti. In: conferenza detta il 27 Gennaio I 884 all'Associazione Magistrale di Camposampiero. Padua: Stab. Tip. Prov. Ditta

L. Penada.

From: Historical Archive of Assicurazioni

Generali, Trieste

Wollemborg L (1884d) L'ordinamento delle casse dei prestiti. In: conferenza detta il 24 Novembre 1884 all'Associazione Agraria Friulana; Aggiuntovi lo Statuto d'una Cassa di Prestiti; lo Statuto d'un Circolo Agricolo e altri Scritti dell'Autore. Verona, Padua: Drucker \& Tedeschi.

From: Historical Archive of Assicurazioni

Generali, Trieste

Wollemborg L (I884e) Stimolare le energie morali assopite. II Raccoglitore 7(I3):

226-227.

From: University of Padua Library

Wollemborg L (I885) Cassa di prestiti di Loreggia. Relazioni del presidente e dei sindaci e Bilancio 1884. Padua: Stab. Tip. Ditta L. Penada.

From: Historical Archive of Assicurazioni

Generali, Trieste

Wollemborg L ( $1886 \mathrm{a})$ Cassa di prestiti di Loreggia. Relazioni del presidente e dei sindaci e Bilancio 1885. Padova: Stab. Tip. Prov. L. Penada.

From: Historical Archive of Assicurazioni

Generali, Trieste

Wollemborg L (1886b) Extract from:

Cooperazione Rurale 15 Agosto 1886. In:

Manuale per le Banche Popolari Italiane, 2nd

edn. Milan: E. Reggiani e C.

From: University of Padua Library

Wollemborg L (1887) La teorica della cooperazione. Giornale Degli Economisti 2(2): |29-|44.

From: JSTOR Archive (online)

$\begin{array}{lll}\begin{array}{l}\text { Open } \\ \text { Archival }\end{array} & \begin{array}{l}\text { Private } \\ \text { Official }\end{array} & \\ \text { Open } & \text { Private } & \text { Monograph } \\ \text { Published } & \text { Official } & \end{array}$

$\begin{array}{lll}\begin{array}{l}\text { Open } \\ \text { Published }\end{array} & \begin{array}{l}\text { Private } \\ \text { Official }\end{array} & \begin{array}{l}\text { This monograph was composed } \\ \text { by } 10 \text { different writings of Leone } \\ \text { Wollemborg }\end{array}\end{array}$

\section{Open Private \\ Published Official}

\section{Open}

Archival

Private

Official

$\begin{array}{ll}\text { Open } & \text { Private } \\ \text { Archival } & \text { Official }\end{array}$

$\begin{array}{ll}\text { Open } & \text { Private } \\ \text { Published } & \text { Official }\end{array}$

$\begin{array}{ll}\text { Open } & \text { Private } \\ \text { Archival } & \text { Official }\end{array}$

Despite the different title, this article has the same content as the publication 'La cassa cooperativa di prestiti di Loreggia' (Wollemborg, 1884d) mentioned above

Monograph: Summary of the general meeting with the members and Annual Report 1884, pp. I-8

Monograph: Summary of the general meeting with the members and Annual Report 1885, pp. I-7

Book: pp. $1-10$ 
Appendix I. (Continued)

List of the primary sources (in chronological Access Authorship Notes on the source order)

Wollemborg L ( I889a) II più antico esempio dell'assicurazione contro i danni della mortalità del bestiame. Giornale Degli Economisti 4(I): 67-69.

From: JSTOR Archive (online)

Wollemborg L (1889b) Les Caisses

Rurales Italiennes. Rapport pour l'Exposition

Universelle de Paris en 1889. Rome: Istituto

Cartografico Italiano.

From: University of Padua Library

Wollemborg L (1890) Le casse rurali

italiane. In: Wollemborg L (2013) 'II

sentimento del bene comune'. Scritti e discorsi

scelti del fondatore della prima Cassa Rurale

italiana (I 883-1929). Rome: Ecra, Pp.

91-107.

Wollemborg L (I89|) La situazione

finanziaria. Giornale Degli Economisti 3(2):

166-175.

From: JSTOR Archive (online)

Wollemborg L (1892) Propaganda per le

casse rurali. In: Wollemborg L (2013) 'II

sentimento del bene comune'. Scritti e discorsi

scelti del fondatore della prima Cassa Rurale

italiana (I 883-1929). Rome: Ecra, Pp.

109-127.

Wollemborg L (1895) Sui provvedimenti legislativi per le casse rurali. In: Wollemborg

L (20I3) 'Il sentimento del bene comune'. Scritti e discorsi scelti del fondatore della prima Cassa Rurale italiana (I 883-1929). Rome: Ecra, Pp. 129-133.

Wollemborg L (I896) Sulla circolazione bancaria. In: Wollemborg L (20I3) 'II sentimento del bene comune'. Scritti e discorsi scelti del fondatore della prima Cassa Rurale italiana (I 883-1929). Rome: Ecra, Pp. 165-173.

Wollemborg L (1898) Sui provvedimenti bancari. In: Wollemborg L (2013) 'Il sentimento del bene comune'. Scritti e discorsi scelti del fondatore della prima Cassa Rurale italiana (I883-1929). Rome: Ecra, pp. |75-20|.

Open Private

Archival Official

Open Private Book: pp. 1-69

Published Official

Open Private Report read by Wollemborg on

Published Official 17 April 1890 at the second Congress of the French urban credit cooperatives

\begin{tabular}{|c|c|c|}
\hline $\begin{array}{l}\text { Open } \\
\text { Archival }\end{array}$ & $\begin{array}{l}\text { Private } \\
\text { Official }\end{array}$ & \\
\hline Open & Private & Published in a book by Parma \\
\hline Published & Official & Stab. Tip e Lit. Luigi Battei \\
\hline
\end{tabular}

Open Private Discourse at the first national

Published Official Congress of the rural credit cooperatives, 5-6 September 1895

Open Private Discourses at the parliament (2I

Published Official December 1896)

Open Private

Discourses at the parliament (29

Published Official December 1898) 
Appendix I. (Continued)

List of the primary sources (in chronological Access Authorship Notes on the source order)

Wollemborg L (1929) La definizione della società cooperativa. In: Wollemborg L (20I3) 'Il sentimento del bene comune'. Scritti e discorsi scelti del fondatore della prima Cassa Rurale italiana (I 883-1929). Rome: Ecra, Pp. |35-| 46.

Epistolario Leone Wollemborg-Luigi Luzzati. In: Wollemborg L (20I3) 'Il sentimento del bene comune'. Scritti e discorsi scelti del fondatore della prima Cassa Rurale italiana (1883-1929). Rome: Ecra, pp. 149-157.

$\begin{array}{ll}\text { Open } & \text { Private } \\ \text { Published } & \text { Official }\end{array}$

Open

Personal

Containing some of the letters

Published exchanged between Leon

Wollemborg and Luigi Luzzati

The primary documentary sources written by Leone Wollemborg are listed and identified (based on Scott, I990: II) by authorship (personal - when produced by a private entity or an individual for personal use; official - when produced by a private or a public entity for an official purpose) and type of access. Additional information is shown in italics: the library or the archive where the document is stored and the structure of the document (if it is a collection of various works). 